\title{
The Enlightement and the Orthodox East's Innovation in Musical Education: "The New Method of Analytical Notation" and the Impact of Logios Ermis
}

\author{
Emmanouel Xynadas, MA, PhD \\ Ecclesiastical Academy of Vella of Ioannina -Greece \\ Evi Psarrou, MA, PhD \\ Ministry of Education- Greece \\ DOI: 10.29322/IJSRP.11.12.2021.p12052 \\ http://dx.doi.org/10.29322/IJSRP.11.12.2021.p12052
}

\begin{abstract}
This study refers to the renewal of the music education of the Greeks during the Enlightenment shortly before the Revolution. It is very interesting to present this reform in the Eastern Orthodox ecclesiastical music, namely the Byzantine Music, of the Eastern Orthodox Church because its members had strongly opposed to the Enlightenment, as there had been many objections to the Greek Enlightenment on behalf of the members of the Orthodox Church. Nevertheless, as revealed in the present study, the Orthodox Church not only accepted the reform but adopted and supported it. Therefore, this paper demonstrates the great achievement of the innovation brought about by the adaptation of the "New Method", a method that simplified the system of neumatic notation and theory of the Byzantine music, by the conservative circles of the Eastern Orthodox Church. At the same time, the importance of the printing press that flourished during the Enlightenment is demonstrated, because it greatly promoted the developments in music education and transmitted the innovative "New Method". Thus, the role of the printing press as a vehicle for the transmission of new ideas is discussed. Specifically, extensive reference is made to the periodical of the era Logios Hermes and its contribution to the spreading of the "New Method". The study presents the historical context within the "New Method" emerged, the influences that Chrysanthos, one of the three creators of the "New Method", had from the West, as well as the method's acceptance, promotion and adoption in the East. All the above are demonstrated in the light of the ideas of the Enlightenment and the contribution of the printing press to the renewal of the Greek thought and the cultivation of the Greeks' revolutionary consciousness.
\end{abstract}

Index Terms- Byzantine Chant, Chrysanthos of Madyta, Enlightement, "New Method", Logios Ermis.

\section{INTRODUCTION}

In 1814 the «New Method» of analytical notation was introduced in the Orthodox Christian Ecclesiastical music bringing about a historic reform. The "New Method", a major development in the art of psaltiki (the art of psalmody ${ }^{l}$ ), was formulated and introduced by the "three teachers, Chrysanthos of Madyta, Chourmouzios Chartophylax and Gregorios Protopsaltis". This method was also described by Chrysanthos in his two treatises published in $1821^{2}$ and $1832^{3}$. The reform of the three teachers is a landmark in the history of Greek Orthodox music as this method is still being used in the official books of the Eastern Orthodox Church and others following Eastern rite. $^{4}$

\section{A FEW WORDS ON THE "NEW METHOD"}

The "New Method" consisted of a simplification of the Byzantine musical symbols, which by the early $19^{\text {th }}$ century had become so complex and technical that only highly skilled psaltes (chanters) were able to interpret them correctly ${ }^{5}$. Besides, it is said that previously

\footnotetext{
${ }^{1}$ The term Psaltiki refers to the vocal tradition of the Eastern Orthodox Church, commonly known as "Byzantine Chant" or else "Byzantine music". See: A. K., Khalil, Echoes of Constantinople: oral and written tradition of the psaltes of the Ecumenical Patriarchate of Constantinople, Ph.D. thesis, University of California, San Diego, 2009, footnote 2, p. 3, where the author explains the reasons of using the term psaltiki instead of Byzatine music.

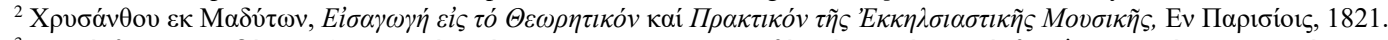

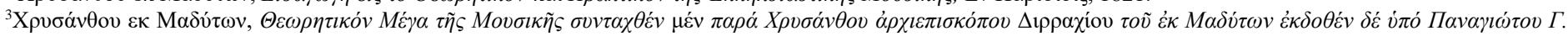

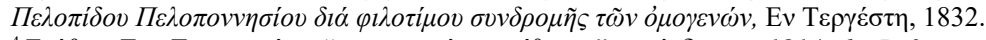

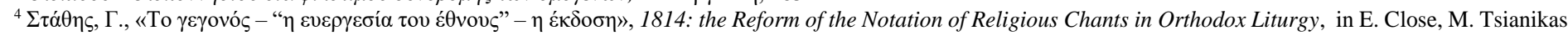
and G. Couvalis (eds.), "Greek Research in Australia: Proceedings of the Sixth Biennial International

Conference of Greek Studies, Flinders University June 2005", Flinders University Department of Languages - Modern Greek: Adelaide, pp. 371 -388.

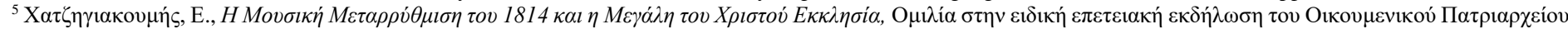

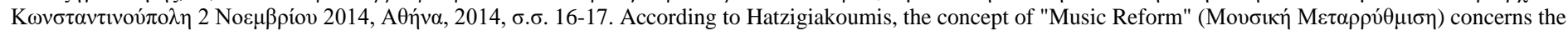
This publication is licensed under Creative Commons Attribution CC BY.
} 
almost 30 years required for the study of Byzantine chant notation, as it had become too complex and unwieldy, whilst it also required years of diligent practise of vocal technique and skills. ${ }^{6}$

The three teachers did not actually changed the system but reconstructed it from the bottom up. In their method they adhered basic aspects of traditional system to a sufficient degree whilst they introduced the elements of Western notation. Specifically, in the notation they preserved the earlier distinction between quantitative and qualitative neumes, but tried to write more detail in their notation using more neumes and fewer ypostases. However, the notation system remained diastematic and the principle by which the diastematic neums operated was also preserved. Furthermore the musical meter was introduced replacing the poetic concept of rhythm. One of the most essential elements - literally an efficient innovation- was the replacement of the polysyllabic note names by monosyllabic names for the instruction of the melodies relating thus the "New Method" to ancient Greek and Western music theory. ${ }^{7}$ Amongst the loans from Western notation was the rhythmical divisions. In addition to these, music printing was crucial as it enabled the uniformity in the interpretation of music over the Eastern Orthodox community, ending thus the diversity of interpretations given to neumes. Having the three teachers developed their new method, and having also obtained the approval of the Holy Synod, they promoted the method amongst their student forming a school in Constantinople that "accepted students from across the nation" 8 and furthermore they interpreted a vast corpus of Eastern ecclesiastical compositions to the new notation.

\section{THE ADAPTATION OF THE “NEW METHOD”}

Following the New Method's approval by the Holy Synod the Ecumenical Patriarchate took a series of actions in supporting and spreading this method. As already said in January 1815 a new public school was founded supporting the work of the "three teachers" in

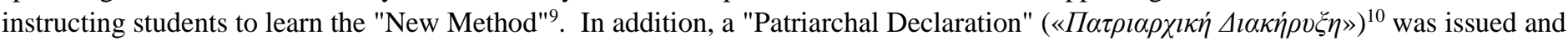

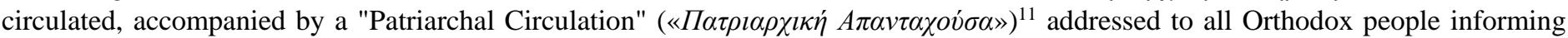
them about the "New System". Through these two patriarchal letters, the news of the "Music Reform" became known, while at the same time the Ecumenical Patriarchate gave assurances about the continuation of the long musical tradition that was formed within the Great Church namely the Patriarchate. ${ }^{12}$ Furthermore, the periodical press of the time contributed significantly at disseminating all relevant

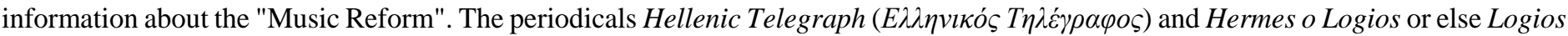

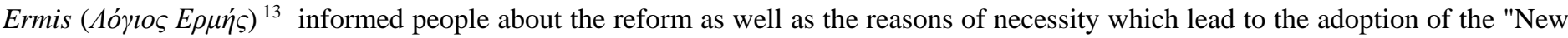
Method". Furthermore all those who wished to obtain the knowledge about the "New Method" were encouraged to travel to Constantinople and study there the "art of psaltiki". In addition, these two periodicals published information in relation to the efficiency of the "New Method's" application in Constantinople, the Danubian Principalities and elsewhere.

\section{THE GREEK ENLIGHTEMENT AND THE PRINTIG PRESS}

From the mid- $18^{\text {th }}$ century the ideas of the Greek Enlightenment spread into the Ottoman Empire where the subjugated Greeks were living under the Sultan's rule. These intellectual ideas contributed decisively to the awakening of the enslaved Greeks who eventually revolted against the Ottomans establishing an independent national state. Merchants of the Greek Diaspora, scholars and enlightened men living in European countries-who had already come in contact with the European spirit of the Enlightenment, contributed to the foundation of educational institutions, such as schools and libraries in the Ottoman Empire where the Greeks lived, aiming at transmitting the new ideas and thus contributing to the awakening of the "Greek nation". The new ideas became better known and easier spread due to the publication of books in Greek especially in the second half of the 18th century and the beginning of the 19th century. In a short time many philosophical and scientific books were translated into Greek. The Modern Greek Enlightenment (or else the Neo-Hellenic Enlightenment) addressed to enslaved people and therefore the matter at hand was the cultivation of national consciousness and the development of $\alpha$ revolutionary movement. The main vehicle of the Greek Enlightenment was the printing activities of the Greeks of the Diaspora. The role of the pre-revolutionary press was important in contributing towards the development of the national consciousness and the revolutionary spirit that eventually lead to a national revolutionary movement. The press of the decade 1811-

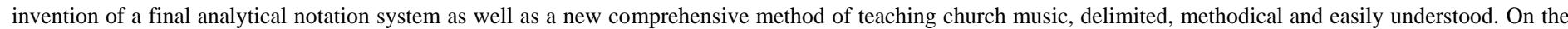

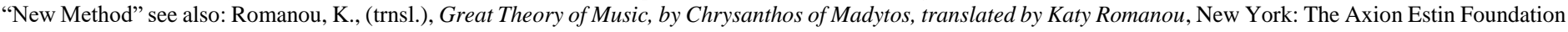
2010, pp. 10-18· Khalil, A. K., Echoes of Constantinople, pp. 29-36, pp. 38-44 and pp. 68-72.

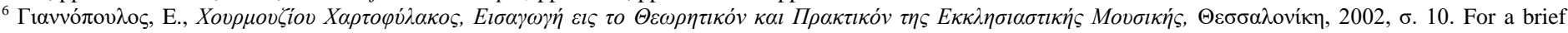

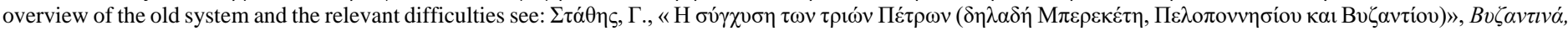

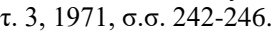

${ }^{7}$ In this way Chrysanthos imported the idea of a solfège system based on that of Western Europe

${ }^{8}$ Khalil, K. A., Echoes of Constantinople, p. 41.

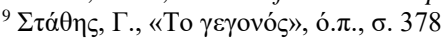

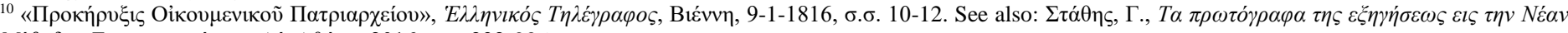

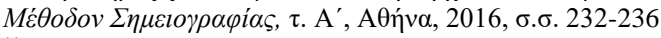

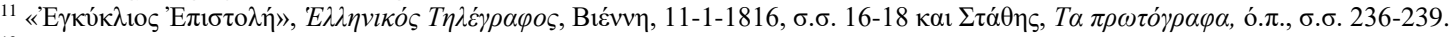

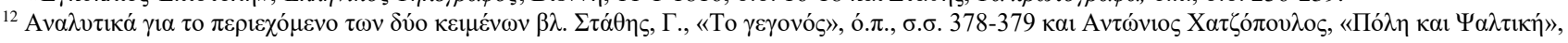
http://fanarion.blogspot.com/2020/09/blog-post_25.html (last access: 19-4-2021).

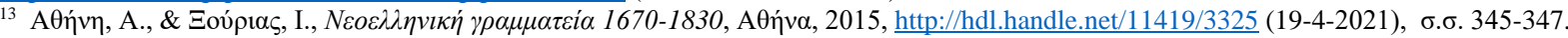

This publication is licensed under Creative Commons Attribution CC BY.

http://dx.doi.org/10.29322/IJSRP.11.12.2021.p12052

WWW.ijsrp.org 
1821 in its entirety, was an expression of the intellectual interests of the Greek scholars as well as the wider cultural and social aspirations of the era during the preparation of the Greek Revolution. ${ }^{14}$

\section{A BRIEF ACCOUNT ON "LOGIOS ERMIS"}

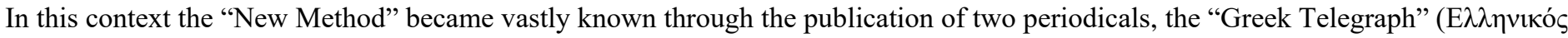

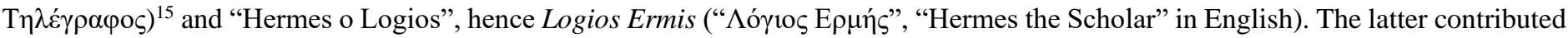
mostly in the spreading of the "New Method". Therefore, a brief reference to the role of "Logios Ermis" should not be omitted as it vastly contributed to the spreading of the new ideas, promoting the importance of education and therefore the awakening of the Greeks during the pre-revolutionary period. From this point of view, "Logios Ermis" was one of the most important periodicals and one of the main advocate of the Modern Greek Enlightenment aiming at informing and enlightening the Greek speaking people within the Ottoman Empire and in the Diaspora.

Logios Ermis was published on a regular basis in Vienna, the most important publishing and spiritual centre of the Geek Diaspora in Europe.$^{16}$ It was printed almost twice a month -with some exceptions- from January 1811 to May 1821 . The periodical's circulation was quite impressive as it extended to almost forty "Greek" -namely cities where the majority of the population was Greek- and European cities. The periodical was supported financially by the Philological Society in Bucharest, the members of which covered part of the printing expenses. Anthimos Gazis, an enlightened Orthodox clergyman and a fervent supporter of Adamantios Korais, was its first editor. ${ }^{17}$ In fact Korais promoted the publication of the periodical believing that through Logios Ermis the ideas of the Enlightenment would pass onto the Greek population of the Ottoman Empire ${ }^{18}$.

Between the years 1814-1815 Logios Ermis faced financial hardships which resulted at a very limited number of published issues, but later on the difficulties were overwhelmed. From 1816 up to 1820 both Theoklitos Farmakidis and Konstantinos Kokkinaris appeared to be the periodical's editors. During this period Logios Ermis' publishing expenses were covered by gifts and subscriptions. Although it was the longest running Greek periodical before the Greek Revolution, Logios Ermis' publication was discontinued when his sole editor Konstantinos Kokkinakis in 1821 was forced at the demand of the Austrian Government, to publish the excommunication set upon the Greek Revolutionaries by the Patriarch Gregorios V.

All published volumes of Logios Ermis cover 5,131 pages whilst the material refers to various topics that could categorized in the fields of education, society, philology, science, medicine, language history, literature, archaeology, philosophy, geography, as well as topics of the Ancient Greek learning- and Antiquity, the Greek language, arts, economics and many other useful subjects which would stimulate the enslaved Greeks' learning, education and cultural resurrection. All scholars' and intellectuals' contributions of this literary journal aimed at the awakening of Greek nationalism and the intellectual resurrection of the Greeks with the ultimate goal being their emancipation and liberation which would lead to the formation of a Greek independent state. Nevertheless, the periodical never published any revolutionary subjects or political and law topics directly referring to an outbreak of a Greek Revolution. Furthermore, although many of Logios Ermis' contributors were members of the Filiki Etaireia ( founded in 1814 aiming at establishing an independent Greek state, they never expressed openly their aspirations through their writings. All the above persons, namely the circle of Logios Ermis pursued their goal aiming at the intellectual awakening of the Greeks thought education. ${ }^{19}$ A possible explanation to this could be the continuous Austrian censorship of the Greeks in Vienna as well as the Austrian Foreign Minister's Clemens von Metternich intelligence service who closely monitored the activities of the Greek community. ${ }^{20}$

\footnotetext{
${ }^{14}$ On the Enlightenment see: Kitromilides, P. M., Enlightement and Revolution: The Making of Modern Greece, Cambridge, MA and London 2013· Demos, R., 'The Neo-

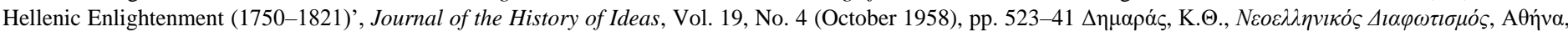

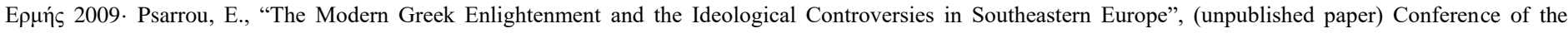
Department of Philosophy, University of Patras on: "Philosophy in Education III: The Ideas of the Enlightenment in the High School Curriculum", 30 March 2012 ·Psarrou, E., "The Effect of the Greek Enlightenment on the Greek Revolution and the position of the Eastern Orthodox Church", International Journal of Social Science and Human Research, vol.4, Issue 09, September 2021, pp. 2537-2540.

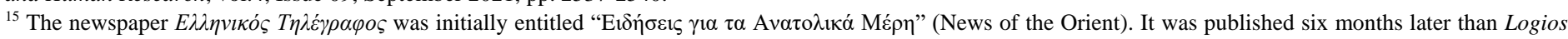
Ermis and existed from 1811 until 1836.

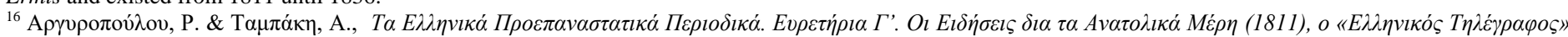

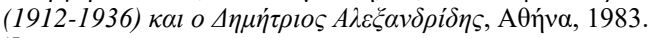

${ }^{17}$ Psarrou, E., "Rigas Feraios and Adamantios Korais: two prominent figures of the Geek Enlightenment", International Journal of Arts Humanities and Social Sciences Studies, vol. 6, issue 11, November 2021, pp. 1-5.

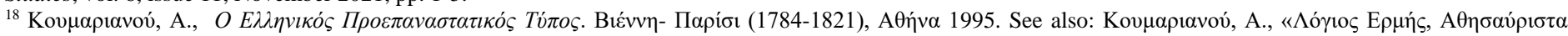

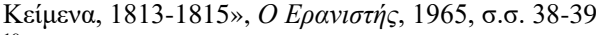

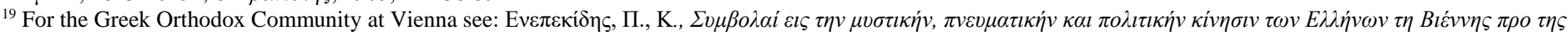

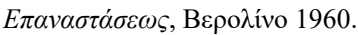

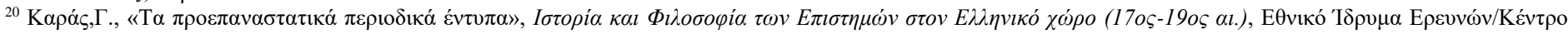

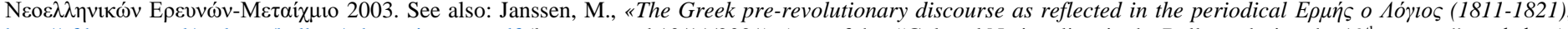
http://cf.hum.uva.nl/natlearn/balkan/athens_janssen.pdf (last accessed 10/11/2021), (part of the: "Cultural Nationalism in the Balkans during the 19 ${ }^{\text {th }}$ century" workshop). This publication is licensed under Creative Commons Attribution CC BY.
}

http://dx.doi.org/10.29322/IJSRP.11.12.2021.p12052

WWW.ijsrp.org 


\section{LOGIOS ERMIS' CONTRIBUTION IN THE DISSEMINATION OFTHE “NEW METHOD”}

As becomes evident by articles published in Logios Ermis the periodical press of the period disseminated information on the progress of the "New Method's" implementation. Apparently this reform in the psalitki became quickly acknowledged both in Constantinople and in the Danubian Principalities.

As becomes evident by the articles published in Logios Ermis the periodicals of the period disseminated information on the progress of the "New Method's" implementation. Apparently this reform in Psalitki became quickly known both in Constantinople and in the

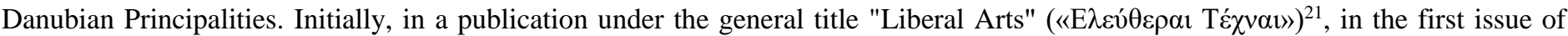

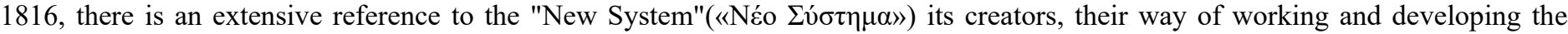
method, as well as their actions for its implementation. In addition, the author refers to the "Ne Method's" approval by the Ecumenical Patriarchate of Constantinople, as well as the Patriarchate's actions for promoting and circulating the method in the provinces of the "provinces of the Patriarchate". Furthermore in the same article, music is described as a "very remarkable science" necessary for the development of people's reason and consciousness, especially given the period of the Enlightenment. In support of his ideas the author republished part of Johann Georg Sulzer's work, the leading German musician of Enlightenment ${ }^{22}$.

A few months later, with a new article Logios Ermis informed his readers about the progress and support of the "New Method" by the clergy, nobles and merchants of Constantinople. In addition, in the same article there are references to the music teachers, who had already studied the "New Method" at the public music school of Constantinople (namely the fourth Patriarchal School of Music) $)^{23}$ and later on they were invited to teach the Psaltiki in several different parts of the Empire ${ }^{24}$.

In May 1817 Logios Ermis published a letter of Chrysanthos to his student Gregory ${ }^{25}$, who had already been in Iasio since 1816 teaching the "New Method"26. Gregory and one more student of the Three Teachers, Petros Ephesios, invented in Bucharest music typography, thus printing for the first time all music elements which were included in the new notational system developed by the Three Teachers ${ }^{27}$. This letter provides interesting information about the implementation and dissemination of the "New Method", both in Constantinople and in other areas, such as the Danubian Principalities, the Aegean islands and Thrace. More specifically, Chrysanthos expresses his satisfaction for the acceptance and support of the New System by the nobles of the Danubian Principalities. The result of their actions contributed significantly to the achievement of the goals set by the three teachers. These goals were relevant to the increase of the people studying the New Method and consequently of the psaltes (chanters) in the churches on the one hand and the rescue and dissemination of the yfos (musical "style" or style of chanting) of the Ecumenical Patriarchate. Thus, according to Chrysanthos, Gregory who was settled in Iasio, where he served both as psaltis and teacher of the Psaltiki (Art of Chanting), had three students sent there by the Metropolitan of Moldavia Benjamin (1812-1821 - 2nd archdiocese) ${ }^{28}$ to learn the "New Method" Apart from these three students, Chrysanthos reported that at the same time Gregory were teaching the New Method to ten more students. At the same period another teacher of the "New Method" would travel from Constantinople to Iasio to take over the education of more students.

Furthermore in the same letter Chrysanthos informs Gregory about the promotion of the "New Method" in Constantinople. He also writes about the preparation of the Doxastarion ${ }^{29}$ which was eventually published in 1820 in Bucharest ${ }^{30}$. Crysanthos also adds that a building had been bought by the Patriarchate to house the public school where the "New Method would be taught"31. At the same time, students and supporters of the three teachers and the "New Method" were being appointed as psaltes in Constantinople. These teachers in turn were trying to attract more students to introduce them to the "New Method". Thus, twenty more students approached Alekos, a student of the Three Teachers, to be taught by him. At the same time Dimitrios Voutiras was admitted to the School of Chios in order to teach the "New Method", whilst Kostis Agiotafetitis was sent to Ainos in Thrace to teach the "New Method". Finally, in relation to the teaching of the "New Method" the information according to which the Protosygkelos (Chancellor) Philotheos actively dealt with the theoretical documentation of the New System, contributing in this way to the progress of the method and its further development.

\footnotetext{
${ }^{21}$ «E

${ }^{22}$ Riley, M., "Civilizing the Savage: Johann Georg Sulzer and the «Aesthetic Force» of Music", Journal of the Royal Music Association, v. 127, no 1, 2002 , pp. 1-2.

${ }^{23}$ «The New Method» which was approved and adapted by the Patriarchal Synod was implemented and taught at the fourth Patriarchal School of Music in the years 1815-1821.

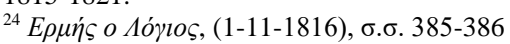

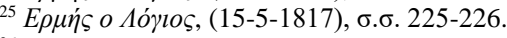

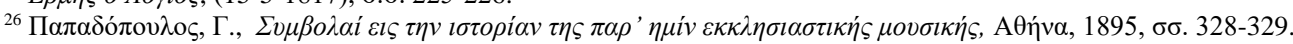

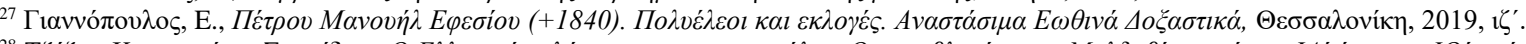

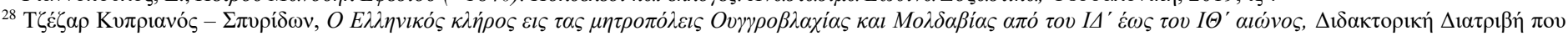

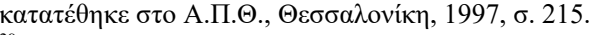

${ }^{29}$ Doxastarion: a music book that contains the doxastika, theotokia and other troparia of fixed and movable feast days.

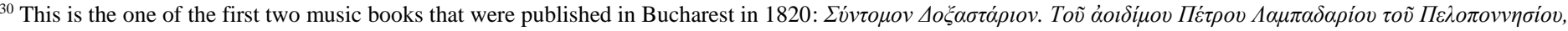

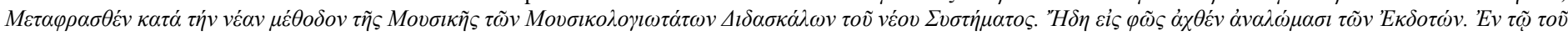

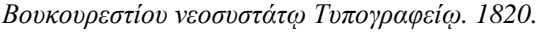

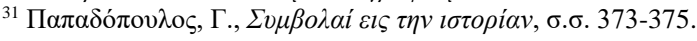

This publication is licensed under Creative Commons Attribution CC BY.
}

http://dx.doi.org/10.29322/IJSRP.11.12.2021.p12052

WWW.ijsrp.org 
Additionally, one more article in Logios Ermis was published according to which we are informed that the "New Method" had been also spread in Odessa ${ }^{32}$. According to this, the Greek residents of Odessa, after building a beautiful church, which had carefully decorated, they invited a psaltis from Constantinople, who would be teaching the new music system to the youth of Odessa. This person was undertaken Anthimos of Constantinople who was said to be an expert in the Psaltiki. ${ }^{33}$

Finally it should be mentioned that in Logios Ermis many more indirect information about the spread of the "New Method" in the

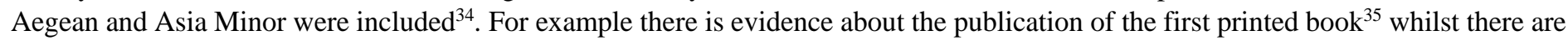
also information about the name of the teachers who taught the Psaltiki in accordance to the "New Method" in various places at newly established schools. Thus, we are informed about Manuel Smyrnaios who taught in Smyrna, Zafirios Smyrnaios in Kydonies and Ioannis

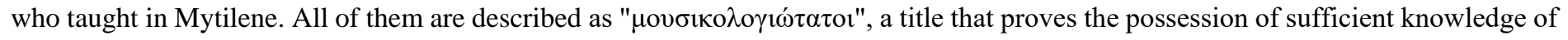
the Psaltiki and the ability to promote it through their teaching.

\section{THE ENLIGHTEMENT AS VEHICLE FOR THE “NEW METHOD”}

The spirit of the Enlightenment is manifested in the reform of the Eastern Orthodox ecclesiastical music (or else Byzantine music). The "New Method" refers the systematic changes that detached the Byzantine music from the old tradition since new elements appeared both in chanting and notation, some of them being influenced by the Western European music. Chrysanthos himself was influenced by the spirit of the Enlightenment and was inspired in inventing the "New Method". He tried to encourage the study of western civilization introducing elements of western music in to the psaltes of the East. Chrysanthos influenced by Jan Jacque Rousseau, attempted to write a general theory of byzantine music within the context of the Enlightenment ${ }^{36}$. Furthermore the changes and following the flourishing of the ecclesiastical music coincides with the glorious revivalof Hellenism because of the Enlightenment. The renewal in music coincides with the efforts for the awakening rebirth of enslaved Greeks a few years before the Greek Revolution.

As already discussed, the Enlightenment's ideas were supported by Logios Ermis, consequently the same periodical supported the "New Method" disseminating all the relevant information. In turn, Logios Ermis was supported by Adamantios Korais which automatically proves that the "New Method" was connected to the Enlightenment. Besides, the "New Method" was invented during the period of change in reason, science, education etc. and therefore it seems to be a natural consequence of the general change. Furthermore, new schools were founded, new teaching methods employed, more people were involved in the educational proses and finally more students had access to learning the "New Method". All these are closely connected to the spirit of the Enlightenment. Besides Chrysanthos' second publication, "The Great Theory of Music" in 1832 provides evidence of the author's influence by the Enlightenment as well as his active involvement in the Enlightenment of the Greeks. Although the "New Method" was in line with the spirit of change in education brought about by the Enlightenment, it should be noted that many elements of the musical tradition of the East still remained and were included in the "New Method". Basically it was a combination ranging from classical writings to contemporary western European theory.

Additionally the printing press of the time, undoubtedly related to the Enlightenment, supported as well as promoted the "New Method" through the periodicals of the period, such as Logios Ermis which - as said already- became the most important vehicle for the transmission of progressive ideas which would ultimately lead to the awakening and the liberation of the Greek people. The importance of printing press should be stressed out as it served as vehicle for the circulation of ideas, knowledge, and information supported the intellectual movement of the Greek Enlightenment.

Apparently the Enlightenment influenced on the one hand the "New Method" and the typography on the other; the printing press in turn supported the "New Method"; in this way a close connection was created between the triptych Enlightenment - "New Method"- printing press of the period.

\section{CONCLUSION}

Concluding the present paper a final reference should be made to the contribution of the Greek printing press and the role of Greeklanguage periodical Logios Ermis in transmitting information and knowledge related to the development of sciences, arts, etc. as well as the dissemination of the "New Method of Analytical Notation" introduced by the Three Teachers among the Greeks of the Ottoman Empire and the Diaspora. The transmission of information on the implementation of the reformed music system was part of the wider

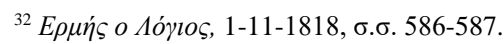

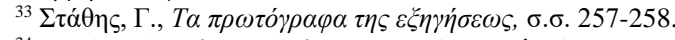

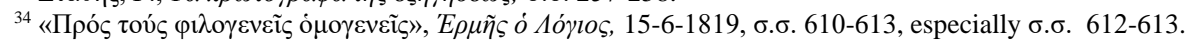

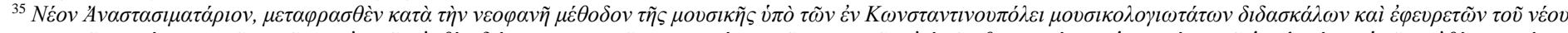

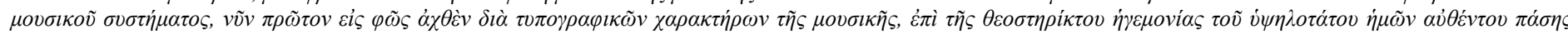

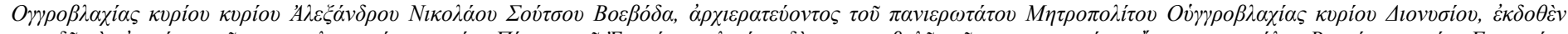

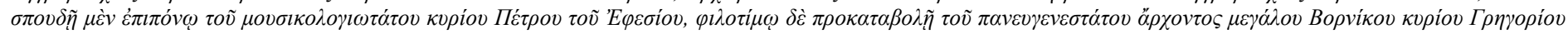

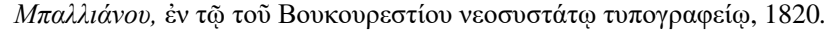

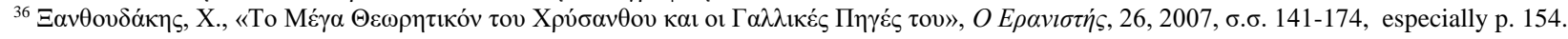

This publication is licensed under Creative Commons Attribution CC BY.

http://dx.doi.org/10.29322/IJSRP.11.12.2021.p12052 
effort of the Greek printing press to the Greek's awakening which would eventually lead to the Greek revolutionary movement and the foundation of an independent state.

\section{REFERENCES}

[1] Demos, R., 'The Neo-Hellenic Enlightenment (1750-1821)', Journal of the History of Ideas, vol.19, No. 4 (October 1958), pp. 523-41.

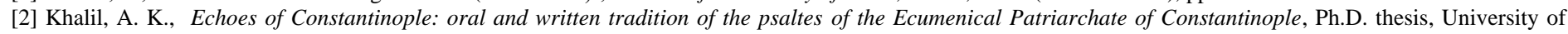
California, San Diego, 2009.

[3] Kitromilides, P. M., Enlightenment and Revolution: The Making of Modern Greece, Cambridge, MA and London 2013.

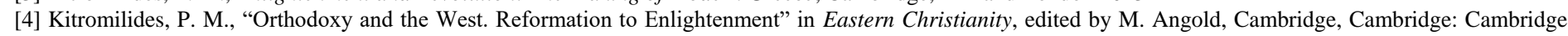
University Press, 2006.

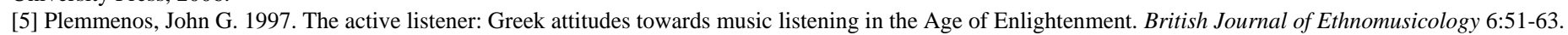

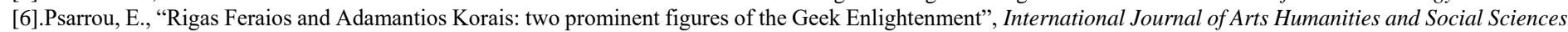
Studies, vol. 6, issue 11, November 2021, pp. 1-5.

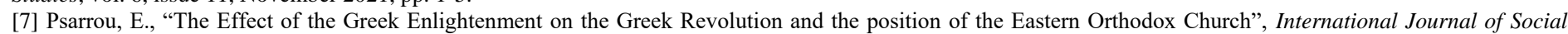
Science and Human Research, vol.4, Issue 09, September 2021, pp. 2537-2540.

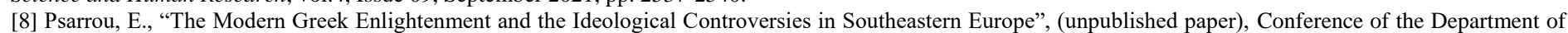
Philosophy, University of Patras on: "Philosophy in Education III: The Ideas of the Enlightenment in the High School Curriculum", 30 March 2012.

[9] Romanou, K., (trnsl.), Great Theory of Music, by Chrysanthos of Madytos, translated by Katy Romanou, New York: The Axion Estin Foundation 2010.

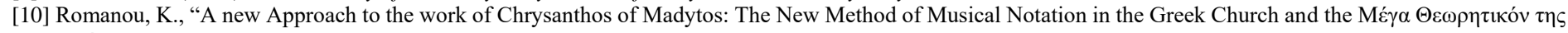
Моvбıќ'`", Studies in Eastern Chant, 1990, pp.1-13.

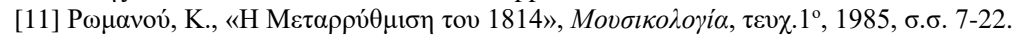

[12] Wellesz, E., A history of Byzantine music and hymnography, 2nd ed., Oxford: Clarendon Press, 1961.

[13]A

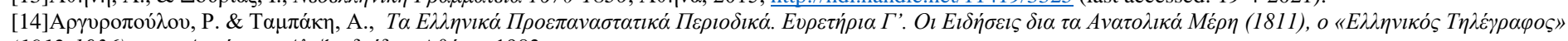

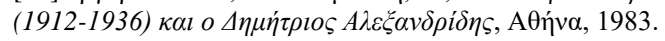

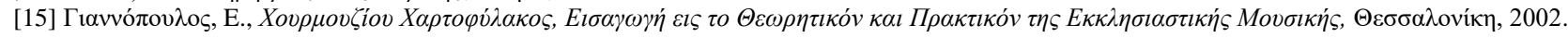

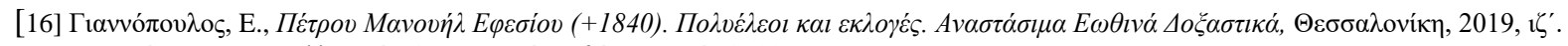

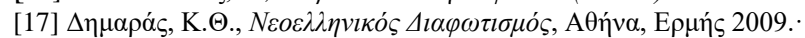

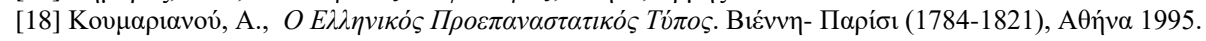

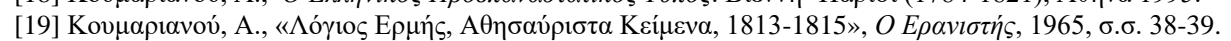

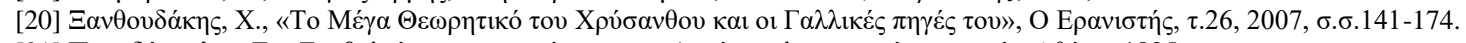

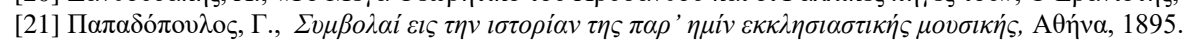

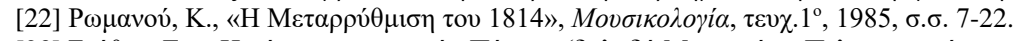

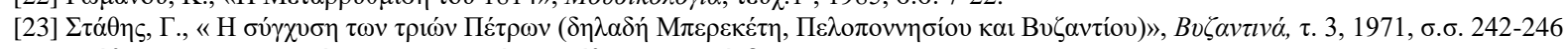

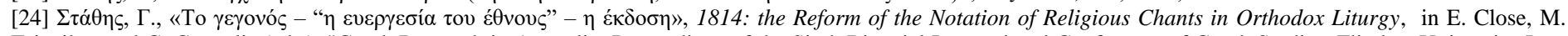

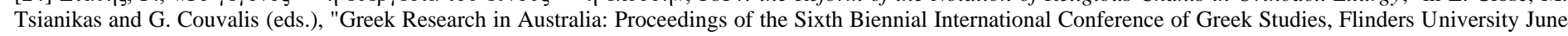
2005", Flinders University Department of Languages - Modern Greek: Adelaide, pp. 371-388.

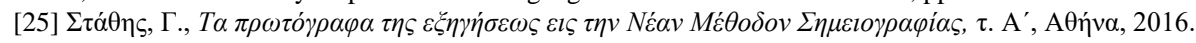

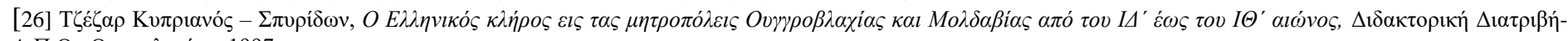

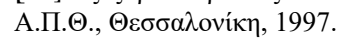

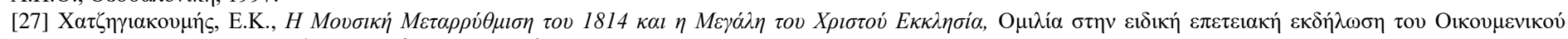

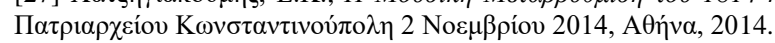

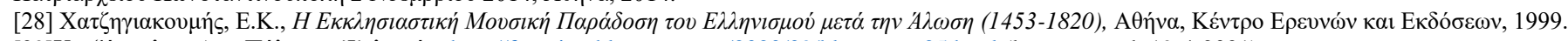

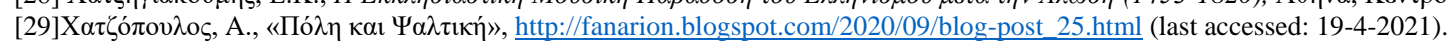

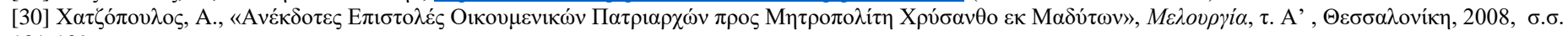
$131-139$.

\section{AUTHORS}

Emmanouel Xynadas, MA, Ph.D, Aristotle University of Thessaloniki- Greece Ecclesiastical Academy of Vella of Ioannina -Greece

e-mail: emmxynadas@gmail.com

Correspondence Author: Evi Psarrou
Evi Psarrou, MA, PhD, University of Birmingham-UK Ministry of Education - Greece e-mail: evipsarou@gmail.com 